\title{
BIMBANG GEDANG SEBAGAI DASAR PENGEMBANGAN KARYA TARI MIKEK
}

\author{
Sari Romundang Wulan \\ Universitas Negeri Yogyakarta \\ E-mail: sari.romundang.wulan@gmail.com
}

\begin{abstract}
Abstrak
Provinsi Bengkulu memiliki beragam seni dan kebudayaan khas adat melayu Bengkulu, salah satunya yaitu Bimbang Gedang. Bimbang gedang, merupakan kesenian adat melayu kota bengkulu dalam rangka acara pernikahan bujang gadis bengkulu ,yang mana pelaksanaan nya melalui prosesiberasan adat untuk memakai dan meminjam adat peradat bimbang yang di pegang oleh rajo penghulu. Tujuan Penciptaan, 1) Sebagai salah satu persyaratan menyelesaikan tugas mata kuliah Penciptaan Seni; 2) Mengungkapkan ide yang berangkat dari tema Bimbang Gedang; 3) Proses pencarian jati diri dan menemukan bentuk dan karakter baru dalam berkarya; 4) Sebagai wujud kreativitas yang memiliki nilai dan inovasi dalam karya seni tari.Rangsang awal dari garapan ini merupakan rangsang idesional karena ide garapan ini didapat dari karya tradisi tari sapu tangan provinsi Bengkulu. Karya tari ini ditampilkan pada acara adat bimbang Bengkulu, yaitu sebuah acara prosesi pernikahan. Dimana pada saat bimbang gedang para pemuda dan pemudi saling berlomba untuk menunjukkan kebolehannya dalam berbagai hal, baik itu menari ataupun bermain musik. Pada kesempatan ini pula pemuda dan gadis saling bertemu dapat menari dan bernyanyi bersama di dalam area, namun terikat dengan norma adat.
\end{abstract}

Kata kunci: Bimbang Gedang, pengembangan, karya tari, Mikek

\section{BIMBANG GEDANG AS A BASIC DEVELOPMENT OF MIKEK DANCE}

\begin{abstract}
Abtsract
Bengkulu has a variety of typical Malay-Bengkulu arts and culture, one of which is Bimbang Gedang. Bimbang gedang is a Malay traditional art in Bengkulu, held during the wedding ceremony of Bengkulu's girls, which is carried out through a procession of customary rice to use and borrow the customs of the wavering adherents held by Rajo Pengulu.The Purpose of Creation, 1) as one of the requirements for completing an Art Creation course; 2) Expressing ideas that depart from Bimbang Gedang theme; 3 ) The process of searching for identity and discovering new forms and characters in the work; 4) as a form of creativity that has value and innovation in the dance art. The initial start of this work is a professional stimulus because the idea of $\dagger$ this work was obtained from the work of Bengkulu's handkerchief dance tradition. This dance is performed at Bengkulu's traditional wavering event, which is a wedding procession. During the moment of the dance, young men and women vied with each other to show their abilities in various things, whether dancing or playing music. During this event, young men and women who meet each other can dance and sing together in the area, but are bound by customary norms.
\end{abstract}

Keywords: Bimbang Gedang, development, Mikek dance 


\section{PENDAHULUAN}

Kebudayaan merupakan sesuatu yang sangat kompleks secara keseluruhan meliputi pengetahuan, kepercayaan, nilai, norma, kesenian, adat istiadat serta kemampuan lainnya yang menjadi sebuah ciri khas masyrakat tertentu. Kesenian di Indonesia terdiri dari berbagai budaya dan adat istiadat. Hal ini memberikan bentuk kesenian yang beraneka ragam mulai dari seni musik, seni tari, seni teater, dan seni rupa yang diwariskan secara turun temurun. Kebudayaan yang ada di Indonesia harus terus dikembangkan selaras denganperkembangan masyarakatnya. Melalui kesenian, hal tersebut mampu mengungkapkan sebuah visi misi dari suatu kebudayaan.

Kreativitas merupakan salah satu aspek penting dalam menghasilkan sebuah karya seni. Karena seseorang akan mampu menciptakan suatu karya dengan ide gagasan, pengalaman hidup serta hasil imajinasi yang luas. Semua manusia terlahir dengan kemampuan berkreasi, namun dengan tingkatan dan kualitas yang berbeda-beda dalam pencapaiannya. Hal ini disebabkan oleh pengaruh yang masing-masing individu dapatkan baik dari faktor internal dan eksternal. Menurut Rogers (78-80) sesorang yang ingin dengan mudah berkreativitas harus tau bagaimana cara menciptakan kondisikondisi eksternal yang mampu memelihara kondisi internal yang diperlukan untuk sebuah kreativitas.

Kreativitas erat kaitannya dengan sebuah imajinasi. Imajinasi sering dikatakan sebagai dasar dari kegiatan kreatif. Karena orangorang yang kreatif memiliki banyak kumpulan imajinasi dan gagasan yang tidak terlihat oleh mata. Seseorang yang ingin mengembangkan kreativitas harus memiliki banyak kesempatan untuk menggunakan imajinasi dan menggembangkannya melalui sebuah media, misalnya dalam bentuk gerak, rupa, dan suara. imajinasi dapat diartikan sebagai proses yang membangun kembali persepsi dari suatu objek, membayangkan sesuatu, mengembangkan khayalan atau daya cipta.

Secara harfiah, istilah seni tari diartikan sebagai proses penciptaan gerak tubuh yang berirama dan diiringi musik yang berlandaskan rasa dan karsa. Namun, beberapa ahli tari memiliki gagasan tersendiri mengenai istilah seni tari. Menurut Soedarsono, Seni tari merupakan ekspresi jiwa manusia yang diwujudkandalam bentuk gerakan tubuh yang indah dan ritmis. Jika ditinjau dari jenis pertunjukan dan partisipasi, seni tari dapat dibedakan menjadi: Tari Partisipatif, ialah tari yang jarang menggambarkan sebuah cerita dan hanya bertujuan untuk interaksi sosial ataupun olahraga saja. Aturan tari jenis ini biasanya terkait larangan dilakukan kedua gender dan usia tertentu. Jenis tari ini dapat berupa tarian rakyat, berkelompok, sosial, dan berpasangan. Tari Teater, merupakan tari yang menggambarkan sebuah cerita dan dipentaskan serta dilengkapi properti khusus. Tujuan utama tari ini ialah sebagai hiburan. Jenis tari ini meliputi, balet, tari Jepang, tari modern, dan lainnya. Berdasarkan koreografinya, seni tari dapat dibedakan menjadi: Tari Tunggal, ialah tari yang diperakan oleh seorang penari atau dikenal juga dengan istilah tari solo. Misalnya, tari Golek dari Jateng. Tari Berpasangan, dalam bahasa latin dikenal dengan istilah pas de duex ataupun dalam bahasa awan disebut duet. Tari ini dilakukan oleh dua orang ataupun berpasangan. Misalnya, tari Topeng dari Jabar. Tari Kelompok, dalam bahasa asing disebut group choreography yaitu tari yang dilakukan minimal oleh dua orang.

Tari kontemporer merupakan jenis tari modern yang tidak lagi terpengaruh unsur tari tradisional. Tari ini menampilkan koreografi unik dan penuh makna. Selain itu, iringan musiknya pun bukan merupakan lagu sederhana yang lazim digunakan melainkan menggunakan program musik komputer dan masa mini. Tak khayal, penikmat yang ingin menikmati jenis seni ini harus berwawasan luas.

\section{METODE}

Proses penciptaan sebuah karya tari menurut Alma M. Hawkins, dituangkan dalam bukunya yang berjudul Mencipta Lewat Tari (Terjemahan dari Buku Creating Trough Dance diterjemahkan oleh Y. Sumandiyo 
Hadi). Buku tersebut menguraikan tentang tiga tahap penciptaan tari yaitu tahapan eksplorasi, improvisasi, dan pembentukan atau forming. Tahapan eksplorsi atau penjajagan berhubungan dengan proses pencarian dan penghayatan. Proses pencarian ruang dimaksud adalah pencarian ide atau gagasan yang nantinya akan diwujudkan ke dalam karya tari. Tahap improvisasi lebih dikenal dengan tahapan percobaan, penunjang dari hasil pencarian sebelumnya. Proses terakhir adalah forming atau pembentukan. Pembentukan merupakan proses akhir yang menunjang proses pencarian dan percobaan yang dilakukan sebelumnya. Pemaparan dari masing-masing tahapan akan dijelaskan sebagai berikut.

a. Eksplorasi

Merupakan tahapan paling awal dalam proses penciptaan tari. Pada tahapan ini pencarian ide atau gagasan menjadi langkah awal, setelah itu penentuan konsep. Kadang-kadang ide bisa muncul kapan saja dan dimana saja. Oleh karena itu, penentuan ide juga bisa diperoleh melalui menonton, mengamati sesuatu, dan bisa berangkat dari pengalaman pribadi

b. Improvisasi

Mengacu pada gerak-gerak tari yang sudah dimiliki, maka penata hanya langsung melakukan penuangan gerak kepada pendukung. Percobaan penuangan gerak ini dilakukan untuk menambahkan gerakan-gerakan. Penuangan gerak tersebut dilakukan atas hasil dari proses penjajagan atau eksplorasi. Pada tahap ini juga dilangsungkan proses penataan musik iringan oleh penata iringan guna mendapatkan kesesuaian iringan dengan garapan yang diinginkan.

c. Forming

Tahap pembentukan atau forming merupakan tahapan akhir dari proses penggarapan tari. Pada tahapan ini juga dilakukan percobaan terhadap kostum dan iringan secara langsung. Tahapan akhir dalam proses kreativitas adalah tahapan penyelesaian atau finishing, yaitu garapan yang sudah terwujud disempurnakan kembali, baik dari segi penghayatan dan kekompakan gerak guna mendapatkan rasa gerak dan rasa estetis yang pas.

\section{PEMBAHASAN}

Perencanaan sebuah karya tari merupakan kegiatan berfikir untuk merencanakan sebuah karya dengan hasil berupa gagasan tari. Gagasan hendaknya langsung berkaitan dengan tema, bentuk gaya tari yang akan dibuat. Dalam proses penggarapan sebuah karya tari dibutuhkan pengetahuan penyusunan berbagai elemen yang harus dipelajari dan dipraktekkan. Karya yang dihasilkan akan Menjadi satu kesatuan yang dapat menyampaikan pesan atau kesan kepada penikmatnya. Hal tersebut meliputi komposisi dari elemen gerak tari, dari motif komposisi kelompok, sampai pada akhirnya menuju ke bentuk tari (Ben Suharto:1985).

Rangsang awal dari garapan ini merupakan rangsang idesional karena ide garapan ini didapat dari karya tradisi tari sapu tangan provinsi Bengkulu. Karya tari ini ditampilkan pada acara adat bimbang Bengkulu, yaitu sebuah acara prosesi pernikahan. Dimana pada saat bimbang gedang para pemuda dan pemudi saling berlomba untuk menunjukkan kebolehannya dalam berbagai hal, baik itu menari ataupun bermain musik. Pada kesempatan ini pula pemuda dan gadis saling bertemu dapat menari dan bernyanyi bersama di dalam area, namun terikat dengan norma adat. Para gadis mendapat tempat di ujung balai, terpisah dengan tirai dan hiasan yang indah.

1. Tema Tari

Tema karya tari ini adalah tari pergaulan muda mudi.

2. Judul Tari

Judul karya tari ini adalah mikek. Mikek artinya dalam bahasa Indonesia artinya memikat. Garapan tari ini dibuat dengan tujuan agar mampu membuat mereka yang menikmati karya tari ini tertarik dan mau mengenal kebudayaan masyarakat Bengkulu. Baik dalam bidanng kesenian ataupun adat istiadatnya. 
3. Orientasi Garapan

Orientasi garapan mengarah kepada budaya Bengkulu. Dengan memadukan gerak melayu, seperti lenggang, langakah step, langkah tak jadi, geraklenggang putri dengan gerak tari Bengkulu. Kemudian dikembangkan sesuai dengan kebutuhan dari garapan tersebut.

4. Properti

Properti yang digunakan dalam tari mikek adalah kain panjang atau selendang.

5. Rancangan Rias dan Kostum

Rancangan tata rias dan kostum disesuaikan dengan kebudayaan yang ada di Bengkulu. Untuk tata rias yang diaplikasikan yaitu tata rias cantik dengan aksesoris jurai (penutup sanggul,warna-warni) dan hiasan kepala. Pada kostum, digunakan kain songket, baju kurung, dan teratai, baju khas masyarakat melayu pada umumnya. Hanya saja pada penampilannya kostum ini dimodifikasi sesuai dengan kebutuhan panggung.

6. Musik

Dalam proses penciptaan karya tari Mikek, iringan musik yang digunakan berorientasi pada iringan gaya melayu khas Sumatera, yaitu Provinsi Bengkulu. Menggunakan permainan beberapa alat musik seperti, akordion, djembe , doll, gendang melayu, bass, simbal, tamborin dan gitar. Iringan dalam tari ini disesuaikan dengan suasana tari dan tujuan dari bentuk garapannya. Hal ini juga didukung oleh dendang atau lirik yang ada pada musik iringan. Berisi pantun yang memiliki arti sebuah ajakan untuk menari dan mengenal kebudayaan tradisi. Point pentingnya adalah agar generasi penerus dalam hal ini anak-anak sekolah terus menarikan atau melestarikan seni budaya daerah. Melalui seni tari, kita bisa mengenal lebih banyak lagi ragam budaya yang ada di Indonesia, salah satunya adalah Bengkulu. Berikut isi lirik dalam musik iringan tari tersebut:

Inilah sembah, jari sepuluh

Salam tak lupa oi sanak, kami sampaikan

Inilah tari, dari Bengkulu
Semoga menghibur, hadirin sekalian

Kalau nak tau, kek daun baru

Batang pepaya oi sanak lebat buahnyo

Kalau nak tau, kota Bengkulu

Beragam-ragam, seni budayo

Reff :

Yuk, berdendang, riang kesana kemari

Bersenang-senang, berjoget dan menari

Yuk, berdendang, riang kesana kemari

Bersenang-senang, berjoget dan menari

Keraslah keras si batang kayu

Janganlah tebang seorang diri

Aduhai cantik budak gadis melayu

Manis senyuman lincah menari (back to reff)

Kalau lah ado kaco yang pecah

Jangan disimpan di dalam peti

Kalau lah ado kato yang salah

Jangan disimpan di dalam hati

\section{KESIMPULAN}

Perencanaan sebuah karya tari merupakan kegiatan berfikir untuk merencanakan sebuah karya dengan hasil berupa gagasan tari. Gagasan hendaknya langsung berkaitan dengan tema, bentuk gaya tari yang akan dibuat. Dalam proses penggarapan sebuah karya tari dibutuhkan pengetahuan penyusunan berbagai elemen yang harus dipelajari dan dipraktekkan. Karya yang dihasilkan akan Menjadi satu kesatuan yang dapat menyampaikan pesan atau kesan kepada penikmatnya. Hal tersebut meliputi komposisi dari elemen gerak tari, dari motif komposisi kelompok, sampai pada akhirnya menuju ke bentuk tari (Ben Suharto:1985).

Rangsang awal dari garapan ini merupakan rangsang idesional karena ide garapan ini didapat dari karya tradisi tari sapu tangan provinsi Bengkulu. Karya tari ini ditampilkan pada acara adat bimbang Bengkulu, yaitu sebuah acara prosesi pernikahan. Dimana pada saat bimbang gedang para pemuda dan pemudi saling berlomba untuk menunjukkan kebolehannya dalam berbagai hal, baik itu menari ataupun bermain musik. Pada kesempatan ini pula pemuda dan gadis saling bertemu dapat menari dan bernyanyi bersama di dalam area, namun terikat dengan norma 
adat. Para gadis mendapat tempat di ujung balai, terpisah dengan tirai dan hiasan yang indah.

\section{DAFTAR PUSTAKA}

Ben Suharto. (1985). Terjemahan Komposisi Tari Sebuah Petunjuk Praktis Bagi Guru. Iklasti : Yogyakarta.

Marsden, William. (1966). The History of Sumatra. Departemen Pendidikan dan Kebudayaan Pusat Penelitian Sejarah dan Budaya Kebudayaan Daerah. 1978. Adat Istiadat Daerah Bengkulu.

Hawkins, Alma M. (2003). Mencipta Lewat Tari. Yogyakarta: University of California Los Angles.
Sara Aloriani. (2012). "The impact of using multimedia on student's academic achivment in the collage of education at King Saud University.

Shaoyan Chena, Yunjian Xia. (2012). 'Research On Application Of Multimedia Technology In College Physical Education.

Panita Wanapiroon. (2014). Development of research-based blended learning model to enhance graduate studentds' research competency and critical thinking skill. 